\title{
Pre-seasonal breeding evaluation of the stallion
}

\author{
Joyce M. Parlevliet \\ Department of Equine Sciences section, Reproduction Faculty of Veterinary Medicine, Utrecht University
}

\begin{abstract}
Summary
Fertility of the stallion is an essential factor in the success of a breeding operation as good semen quality is a prerequisite for a good breeding performance. Therefore, pre-seasonal evaluation of stallion reproductive performance is of importance. In the Netherlands almost all breeding associations require a breeding soundness evaluation before a stallion is registered as a breeding stallion. Each year more than 600 young (mostly three-year-old) stallions are evaluated on reproductive characteristics as semen quality and external genital organs (testicles and epididymides). Criteria for acceptance of a stallion for breeding vary between breeding associations

Semen evaluation prior to breeding has been proven to be a valuable test for predicting stallion fertility in the first breeding season. As a high number of mares $(>300$ ) can be inseminated from one stallion insight in the semen production is necessary. Therefore, this production should be evaluated (for ten days) to estimate the daily sperm output (DSO) at the beginning of the breeding season. In an Al-program the semen can be used either locally, shipped to the mare-owners place or to another stud farm. Shipment of semen requires an adequate storage procedure to ensure minimal loss of semen quality. Semen can either be stored chilled (short term) or frozen (long term). The quality of semen after storage is highly dependent on the quality of the semen before storage and will at best approximate, but never exceed the quality of fresh semen. Therefore the storage ability of chilled semen should also be tested at the beginning of the breeding season. Then the management of the stallion can be adapted depending on the semen quality and the number of mares to be served to optimize breeding results and minimize costs.
\end{abstract}

Keywords: $\quad$ stallion, breeding soundness, semen quality

\section{Zur vorsaisonalen Untersuchung des Zuchthengstes}

Die Fertilität des Hengstes ist ein wichtiger Faktor für den Erfolg des Zuchtbetriebes, so wie eine gute Samenqualität Voraussetzung für eine befriedigende Durchführung der insemination ist. Daher ist die Bestimmung der Reproduktionsleistungsfähigkeit des Hengstes vor der Zuchtsaison essentiell. Fast alle niederländischen Zuchtverbände fordern eine Zuchttauglichkeitsüberprüfung bevor ein Hengst als Zuchthengst registriert wird. Jedes Jahr werden mehr als 600 junge (meist dreijährige) Hengste bezüglich der Samenqualität und der externen Genitalorgane (Hoden, Nebenhoden) überprüft. Die Anforderungskriterien variieren zwischen den Verbänden.

Um die Fertilität des Hengtes in der ersten Zuchtsaison vorherzusagen, hat sich die Bestimmung der Samenqualtiät vor dem Decken als wertvoilster Test bewährt. Ein Einblick in die Samenproduktion ist notwendig, kann doch eine große Anzahl von Stuten (> 300) mit dem Samen eines Hengstes belegt werden. Aus diesem Grund sollte die tägliche Spermienproduktion (daily sperm output - DSO) über einen Zeitraum von 10 Tagen zu Beginn der Saison bestimmt werden. Die instrumentelle Samenübertragung erlaubt den Einsatz des Samens vor Ort sowie dessen Transport zum Gestüt. Der Versand erfordert eine adäquate Lagerung um einen nur minimalen Verlust an Samenqualität zu garantieren. Der Samen kann entweder gekühit - für einen kurzen Zeitraum - oder gefroren - für einen langen Zeitraum - werden. Die Samenqualität nach Lagerung ist in erster Linie von der Ausgangsqualität abhängig, sie ist bestenfalls annähernd so gut, kann aber nie die Qualität von Frischsamen erreichen. Daher sollten die Lagerungseigenschaften von gekühltem Samen ebenfalls zu Beginn der Zuchtsaison getestet werden. In Abhängigkeit von der Samenqualität und der Anzahl der zur Besamung anstehenden Stuten kann dann der Einsatz des Hengstes geplant werden, um beste Zuchtergebnisse und geringste Kosten zu erzielen.

Schlüsselwörter: Hengst, Zuchttauglichkeit, Samenqualität

\section{Breeding soundness evaluation}

Semen of good fertilizing capacity is a prerequisite for obtaining good fertility results on a studfarm (Amann 1981; Dowsett and Pattie 1982; Voss et al. 1982; Pickett et al. 1987; Love et al. 1991; Jasko et al. 1991; Pickett 1993; Parlevliet et al. 1994). Fertility results of a stallion may be markedly influenced by the number of mares a stallion covers and the different ways fertility is expressed. Foaling data are the ultimate proof of the fertility of a stallion (McDowell et al. 1992). However the best method to predict the fertilizing capability of maiden stallions is the clinical examination of the reproductive organs and laboratory assessment of semen quality (Amann, 1981, Colenbrander et al. 1992a).
Testis size is a valuable parameter as sperm production (daily sperm output) is positively correlated to testis size (Pickett et al. 1987; Pickett et al. 1989; Love et al. 1991). Testis consistency provides information on the functionality of the testicle as abnormalities like extreme softness, hardness or irregularity may be associated with insufficient sperm production (Pickett et al. 1987; Pickett 1993).

Evaluation of stallion semen is routinely done by visual or computerized estimation of the percentage of (progressive) motile spermatozoa and by the assessment of percentage of cells with normal or abnormal morphology by light microscopy. Visual estimation of percentage of motile spermatozoa of an ejaculate in comparison with the 'pregnan- 
cy' rate obtained from that ejaculate has been used to evaluate stallion semen (Jasko et al. 1990). The motility of fresh or frozen thawed sperm (assessed by a computerized system for motility evaluation) of 'good' and 'bad' fertilizing stallions has been evaluated and motility and fertility are positively correlated (Jasko et al. 1988; Blach et al. 1989; Andersson and Katilla 1992). Several methods for evaluating sperm morphology have been reported (Pickett et al. 1987; Colenbrander et al. 1992b; Parlevliet et al. 1992). Assessment of morphology by either light or electron microscopy has been performed and evaluation of dye exclusion has been studied (Pickett and Back 1973; Bielanski et al. 1979). Simple evaluation techniques include formalin fixation or aniline blue eosin staining. More advanced staining techniques with fluorescent markers are used for assessment of the plasma membrane integrity and integrity of the acrosomal membrane (Malmgren et al. 1994; Cheng et al. 1996), but require costly equipment and are relatively time consuming.

In the Netherlands 3-year-old Dutch Warmblood stallions selected for breeding have to undergo a breeding soundness test which consists of an evaluation of the external genital organs and the semen quality: The scrotum is inspected and palpated. The length and width of the testicles are measured. The testicles are examined for symmetry, conformation, consistency and location. The epididymides are palpated to assess size, symmetry, consistency and location. Subsequently, two consecutive ejaculates of each stallion are collected, at $1 \mathrm{~h}$ intervals using a teaser mare as a dummy and collecting the semen with an artificial vagina (Hauptner or Colorado State University model). The ejaculates are filtered through a gauze. The volume of the ejaculate $(\mathrm{ml})$ is measured after filtration of the raw semen through a gauze in a graduated cylinder.

Progressive motility (\%) of the coded semen sample diluted with an egg-yolk-extender (Rasbech 1984) (dilution 1:3 - 1:6, depending on the concentration) is estimated by two experienced technicians: this was done using a prewarmed $\left(37^{\circ} \mathrm{C}\right.$ ) phase contrast microscope (Olympus model $\mathrm{BH} 2$ ) at $150 \times$ magnification. The sperm concentration is estimated with a Bürker Türk counting chamber (a haemocytometer) (NIFA, Leeuwarden), correcting for dilution by calculation. Immediately after semen collection and filtration, a smear of the native semen with the aniline blue eosin staining (van der Schaaf 1954) is prepared and then dried. With this stain the viable spermatozoa are unstained (intact plasma membrane) and the 'dead' spermatozoa are stained red. The morphology and viability of 200 spermatozoa are assessed under bright-field illumination $(1000 \mathrm{x})$. If the first $200 \mathrm{did}$ not include 100 unstained cells, an additional number of cells are included in the assessment to reach a minimum of 100 unstained cells. Assessment of spermatozoa morphology is based on the criteria of Bretschneider (1948), which categorize the following characteristics: abnormal acrosome, abnormal head-shape, abnormal neck, abnormal midpiece, curved tail, excentric tail implant, cytoplasmatic droplet neck, cytoplasmatic droplet midpiece and normal cells. A sperm cell is placed in one class of abnormality only (the most proximal one). The percentage of morphologically normal live spermatozoa (MNA) (normal + cytoplasmatic droplets + eccentric tail implant) is calculated. The morphology of stained (dead) sperms is not included in this calculation of morphologic normal spermatozoa as this category of cells is non-motile.

The volume $(\mathrm{ml})$ is multiplied by the concentration $\left(10^{6} \mathrm{ml}^{-1}\right)$, the $\%$ of progressive motile sperms and the \% morphologically normal live spermatozoa to obtain the total number of motile morphologically normal spermatozoa (TMN). The average motility, morphologically normal live spermatozoa, and the total number of motile morphologically normal spermatozoa from two ejaculates are also calculated.

The reproductive characteristics of the riding and carriage type of the Dutch Warmblood horses are presented in Table 1.

Tab. 1: Reproductive characteristics of the riding type ( $n=318$ ) and carriage type $(n=80)$.

Reproduktionscharakteristika von Reitpferden $(n=318)$ und Zugpferden ( $n=80)$.

\begin{tabular}{|l|c|c|}
\hline Reproduct. characteristic & Riding type & Carriage type \\
\hline Gelfree volume (ml) & $64.3 \pm 0.7^{*}$ & $67.4 \pm 1.5^{*}$ \\
\hline Progr. motile (\%) & $70.0 \pm 0.2^{*}$ & $66.4 \pm 0.3^{\star}$ \\
\hline $\begin{array}{l}\text { Spermconcentration }\left(10^{6} \mathrm{ml}^{-1}\right) \\
\text { Total Sperm.conc. (106) }\end{array}$ & $214.3 \pm 4.9^{*}$ & $174.2 \pm 9.8^{*}$ \\
\hline $\begin{array}{l}\text { Morphologically normal } \\
\text { unstained (\%) }\end{array}$ & $66.5 \pm 0.2$ & $65.1 \pm 0.5$ \\
\hline $\begin{array}{l}\text { Total number of motile } \\
\text { morphologically normal } \\
\text { spermatozoa (106) }\end{array}$ & $5556.2 \pm 105.3^{*}$ & $4375.1 \pm 209.5^{*}$ \\
\hline $\mathrm{pH}$ & $7.5 \pm 0.0$ & $7.5 \pm 0.0$ \\
\hline
\end{tabular}

Values are LS means \pm sem, $n=318$ (riding type) and $n=80$ (carriage type). * Significant difference between types $(P<0.05)$.

Criteria for acceptance as a breeding stallion are set by the breeding association. Each year about $8 \%$ of the warmblood stallions fail to pass the breeding soundness test. Young stallions that just acquire the minimal values of parameters of the semen will have fertility problems during the breeding season when they have to serve more than 50 mares or when semen has to be stored and transported. Prediction of the breeding potency of stallions can therefore be of great benefit for the studfarm owner and for the mare owner.

\section{Semen quality and fertility}

An inverse relationship between the percentage of spermatozoa with primary abnormalities and fertility has been reported by Bielanski (1975). Differences between stallions in breeding results can be caused by differences in semen quality. The variation in semen quality explains over $80 \%$ the variation in fertility (Jasko et al. 1991). Indices to evalu- 
ate fertility in horses are e.g. foaling rate (per season or per cycle), per cycle pregnancy rate or the number of services per mare required to achieve a pregnancy (Dowsett et al. 1984; Pickett et al. 1987; McDowell et al. 1992). Other parameters for breeding performance of a stallion are the first cycle pregnancy rate or the first cycle non-return (into a next oestrus after insemination) rate (Bruin et al. 1992, Heiskanen et al. 1994; van Buiten et al. 1994). In contrast to other species, like the bovine and the porcine, which demonstrate a small variation in pregnancy rate, $68-72 \%$ (Lansbergen et al. 1996), and 85-90\% (Colenbrander and Grooten 1991), respectively, there is a wide variation in first cycle pregnancy rates (35-65) for mares bred with diluted (unchilled or chilled) semen (Samper et al. 1991. Heiskanen et al., 1994). However as pregnancy diagnosis is not always performed, the percentage of animals which do not return into oestrus after insemination (non-return rate) is used in the cattle A.I. industry (den Daas 1992).

It would be interesting to see whether a relatively small variation in semen quality between selected three year old stallions would be reflected by differences in fertility performance. Hence, the semen quality of these stallions before breeding were correlated with the breeding results from the first breeding season (Table 2) (Parlevliet and Colenbrander 1999).

It was concluded that the morphology of the spermatozoa was best correlated with the first cycle non-return rate of the young stallions. The pregnancy rate for further cycles of the foaling rates were not a good indication for a stallion's fertility performance as after unsatisfactory pregnancy results obtained in the first cycle management was adapted.

\section{Hereditability of semen quality}

Little is known about average values for the morphology of the live spermatozoa of stallions and the variation in the population that occurs.

The possible sources of variation in stallion fertility and semen quality of different breeds or special populations are not well known. In the bull hereditary effects are found on semen quality and libido (Udala 1988). Sperm concentration in an ejaculate seems to be heritable, according to the experiments with bull twins (Bane 1954). There also is a hereditary positive correlation on male and female reproductive characteristics in cattle (Hansen 1979; Kieniger 1983).

Studies involving the reproductive characteristics of horses suggest that the influence of breed is significant (Hendrikse 1966; Dowsett and Pattie 1982; Voss et al. 1982; Dowsett and Pattie 1987). Inbreeding negatively affects fertility in horses (Mahon 1982; Cochran et al. 1984; Klemetsdal 1989). Hereditary aspects may play a role in the semen quality of stallions. Hence, selection can be important. Criteria for selection of a stallion on his reproductive characteristics have to be defined and the variation in sperm quality of the population has to be assessed to select for semen

Tab. 2: Reproductive characteristics before breeding (mean over 2 ejaculates) and fertility performance of 3-year-old stallions in their first breeding season

Reproduktionscharakteristika vor dem Zuchteinsatz (durchschnittlich 2 Ejakulate) und Zuchterfolg 3-jähriger Hengste in ihrer ersten Zuchtsaison.

\begin{tabular}{|c|c|c|c|c|c|c|}
\hline stallion & $\begin{array}{l}\text { mean progr. } \\
\text { motility }\end{array}$ & $\begin{array}{c}\text { mean MNA } \\
\text { (abn acrosome \%) }\end{array}$ & $\begin{array}{l}\text { mean TNM } \\
{ }^{\star} \text { million }\end{array}$ & $\begin{array}{c}\text { total number } \\
\text { of mares inseminated }\end{array}$ & $\begin{array}{l}\% \text { non return } \\
\text { first cycle } \\
\text { (no. of mares) }\end{array}$ & $\begin{array}{l}\text { foaling } \\
\text { rate }(\%)\end{array}$ \\
\hline 1 & 76 & $64(3)$ & 4477 & 282 & $82(230)$ & 80 \\
\hline 2 & 68 & $63(3)$ & 5534 & 63 & $54(34)$ & 66 \\
\hline 3 & 70 & $57(27)$ & 3242 & 51 & $47(24)$ & 73 \\
\hline 4 & 70 & $69(10)$ & 11648 & 66 & $53(35)$ & 81 \\
\hline 5 & 78 & $59(26)$ & 2741 & 115 & $59(68)$ & 70 \\
\hline 6 & 78 & $76(1)$ & 6511 & 51 & $63(32)$ & 62 \\
\hline 7 & 75 & $73(6)$ & 3866 & 45 & $77(35)$ & 59 \\
\hline 8 & 70 & $61(7)$ & 3016 & 46 & $65(30)$ & 68 \\
\hline 9 & 73 & $54(10)$ & 2422 & 105 & $46(48)$ & 75 \\
\hline 10 & 75 & $67(12)$ & 7633 & 23 & $57(13)$ & 72 \\
\hline 11 & 80 & $77(3)$ & 9720 & 122 & $73(89)$ & 71 \\
\hline 12 & 58 & $54(3)$ & 3879 & 35 & $54(19)$ & 83 \\
\hline 13 & 70 & $26(28)$ & 3033 & 51 & 27 (14) & 36 \\
\hline mean & $72 \pm 6$ & $62 \pm 13(11 \pm 10)$ & $5209 \pm 2899$ & $81 \pm 68$ & $58 \pm 15$ & $69 \pm 12$ \\
\hline
\end{tabular}

MNA = percentage of unstained (viable) spermatozoa with normal morpholog; TNM = total number of morphologically normal motile spermatozoa 
quality. It is possible to improve semen quality by selective breeding. We investigated the hereditary effects on semen quality in semi-siblings (> 3) of 66 Dutch Warmblood stallions (Table 3) (Parlevliet et al. 1994). These data show that there is a tendency to hereditary, but the variation is quite high, because the family size varies from three to eight male offspring per stallion. It would be useful to exclude those stallions from breeding that pass poor semen quality on to their offspring. It is beneficial to select for reproductive characteristics to give preference to stallion lines with a good semen quality.

Tab. 3: Hereditary effects in semen quality. P-value of reproductive characteristics of semi-siblings (> 3) of 66 stallions.

Hererditäre Effekte auf die Samenqualität. P-Werte der Reproduktionscharakteristika von Halbgeschwistern (>3) von 66 Hengsten

\begin{tabular}{|lc|}
\hline Reproductive characteristic & P - value \\
\hline Gelfree Volume $(\mathrm{cm})$ & $<0.03$ \\
\hline Progr. Motile (\%) & $<0.03$ \\
\hline Sperm.concentration $\left(10^{6} \mathrm{ml}^{-1}\right)$ & $<0.0005$ \\
\hline Total no. of sperm. $\left(10^{6}\right)$ & $<0.11$ \\
\hline Morph. Norm. Unstained (\%)(MNA) & $<0.07$ \\
\hline TM N $\left(10^{6}\right)$ & $<0.07$ \\
\hline pH & $<0.63$ \\
\hline
\end{tabular}

${ }^{+} P$ value of reproductive characteristics of semi-siblings $(>3$ ) of 66 stallions

\section{Evaluation of a stallion for an Al-program}

In the Netherlands, the large number of mares to be bred by one stallion (up to 300 per year), the shipment of fresh chilled semen and the use of frozen of semen as over $80 \%$ of the Warmblood broodmares are inseminated artificially, require a good semen quality and quantity from the stallion. Therefore the semen quality, quantity and semen storage ability of a stallion used in an Al-program should be tested over at least a 10-days period at the beginning of the breeding season and controlled during the breeding season regularly. If the daily sperm output (semen production) of a stallion is known, the management can be adapted so that optimal fertility results can be obtained. Apart from the semen production, the semen of the Al-stallion should be free from pathogens (Parlevliet et al. 1997). The storage of the semen can be either short term (fresh chilled) or long term (frozen). The preparation of fresh chilled semen can be done according to the following principle: The ejaculate is filtered through a gauze (to remove the gel), washed and diluted with extender. In the Netherlands the extender is mostly enriched with egg-yolk (Parlevliet 1997). Insemination doses are prepared at a total number of 600 million morphologically normal motile spermatozoa (TNM) in $15 \mathrm{ml}$ tubes. The semen is cooled to $50^{\circ} \mathrm{C}$ during 2 hours and stored on a roller bench till use or shipment. For freezing purposes, an ejaculate of the horse is collected two or three times per week during the non-breeding season. The gel-free ejacu- late is diluted with an extender and washed. Thereafter the pellet is resuspended in freezing extender containing glycerol as a cryoprotectant. The spermatozoa (at a high concentration) are packed in $0.5 \mathrm{ml}$ straws and frozen in a programmable controlled freezer and stored in liquid nitrogen till use (Parlevliet 1997). The advantage of frozen semen is that it can either be used when the semen has to be transported over a long distance (export) or when the number of mares offered for breeding per day exceeds the daily semen output of the stallion during the breeding season. As the quality of storage is highly dependent on the quality of the semen before storage and will be at best approximate, but never exceed the quality of fresh semen, only the stallions with excellent semen quality and quantity should be used for breeding.

Ways to express fertility include non return rate, per cycle pregnancy rate, per season pregnancy rate (Jasko et al. 1990; McDowell et al. 1992). Fertility results calculated by using non return rate tend to overestimate the fertility of a stallion.

\section{Literature}

Amann, R.P.M. (1981): A critical review of methods for evaluation of spermatogenesis from seminal characteristics. J. of Androl. 2, $37-58$.

Andersson M, Katila T. (1992): Evaluation of frozen-thawed stallion semen with a motility analyser. 12th Int Congr Anim Reprod, 1837-1839.

Bane A. (1954): Studies on monozygous cattle twins. IV. Sexual functions of bulls in relation to heredity, rearing intensity and somatic conditions. Acta Agr Scand; 4, 95-208.

Bielanski W. (1964): Comparison of the number of spermatozoa in the successive ejaculates during depletion tests in stallions, rams and bulls. Proc 5th Int Congr Anim Reprod \& Al; 4, 645-650.

Bielanski W. (1975): The evaluation of stallion semen inaspects of fertility control and its use for artificial insemination. J Reprod Fert; 23, 19-24.

Bielanski W, Kaczmarski F. (1979): Morphology of spermatozoa in semen from stallions of normal fertility. J Reprod Fert; 27, 39-45.

Blach EL, Amann RP, Bowen RA, Frantz D. (1989): Changes in quality of stallion spermatozoa during cryopreservation: Plasmamembrane integrity and motion characteristics. Theriogenology; 2, 283-298.

Bretschneider, L.H. (1948): Een normentafel ten gebruike bij de morphologische beoordeling van stierensperma. Tijdschrift voor Diergeneeskunde 73, 421-433.

Buiten, A. van, Bruin, G., Parlevliet, J.M. and Colenbrander, B. (1994): Factors influencing fertility in the horse. Proc. Eur. Ass. Anim. Prod, 45, Edinborough, UK, 366.

Bruin, G., Colenbrander, B., Fontijne P., Creemers, J.J.M. and Spek, M. van der. (1992): Fertility management and pregnancy rates on a studfarm. NRLO-rapport, Den Haag 92/21, 16-17.

Cheng, F.P., Fazeli, A.R., Voorhout, W.F., Marks, A., Bevers, M.M. and Colenbrander, B. (1996): Use of PNA (Peanut Agglutinin) to assess the acrosomal status and the zona pellucida induced acrosome reaction in stallion spermatozoa. J. of Androl. 17, 674-682.

Cochran ED, MacCluer JW, Weitkamp LR, Pfennig DW, Boyce AJ. (1984): Inbreeding and reproductive performance in Standardbred horses. J Hered; 75, 220-224.

Colenbrander, B. and Grooten, H.J. (1991): Swine Al with liquid semen in the Netherlands. Reprod Dom Anim. Boar semen preservation II, (Suppl. 1), 315-316. 
Colenbrander B, Puyk H, Zandee AR, Parlevliet JM (1992a) Evaluation of the stallion for breeding. Acta Vet Scand; 88, 29-38.

Colenbrander, B., Fazeli, A.R., Buiten, A. van, Parlevliet, J., Gadella, B.M. (1992b): Assessment of sperm cell membrane integrity in the horse. Acta Vet. Scand. 88, 49-58.

Daas, N. den. (1992): Laboratory assessment of semen characteristics. Anim. Reprod. Sci. 28, 87-94.

Dowsett, K.F. and Pattie, W.A. (1982): Characteristics and fertility of stallion semen. J. Reprod Fert. (Suppl. 32), 1-8.

Dowsett, K.F., Osborne, W. and Pattie, W.A. (1984): Morphological characteristics of stallion spermatozoa. Theriogenology 22, 5 , 463-472.

Dowsett, K.F. and Pattie, W.A. (1987): Variation in characteristics of stallion semen caused by breed, age, season of year and service frequency. J. Reprod. Fert. (Suppl 35), 645-647.

Hansen H. (1979): Genetic investigations on male and female fertility Livest Prod Sci; 6. 325-334.

Heiskanen, M.L., Huthinen, M., Pirhonen, A. and Mäenpää, P. (1994): Insemination results with slow-cooled stallion semen stored for approximately 40 hours. Acta Vet. Scand. 35, 257-262.

Hendrikse J. (1966): Het sperma van normaal bevruchtende dekhengsten. Tijdschr Dierg; 91, 300-311.

Jasko DJ, Little TV, Smith K, Lein DH, Foote RH. (1988): Objective analysis of stallion sperm motility. Theriogenology; 6, 1159-1167.

Jasko, D.J., Lein D.H. and Foote, R.H. (1990): Determination of the relationship between sperm morphologic classifications and fertility in stallions; 66 cases (1987-1988). J. Am. Vet. Med. Ass. 3 (1), 389-394.

Jasko, D.J., Little, T.V., Lein, D.H. and Foote, R.H. (1991): Determination of stallion semen quality and its relationship with fertility. J. Reprod. Fert. (Suppl 44), 649-650.

Kieniger J. (1983): Populationsgenetische Analysen für Fruchtbarkeitsmerkmale beim Rind. Diss. Hohenheim, Germany,.

Klemetsdal G, Johnson M. (1989): Effect of Inbreeding on Fertility in Norwegian Trotter. Livest Prod Sci; 21, 263- 272.

Lansbergen, L.M.T.E, Bosch, J., Zuidberg, C.A., Wagtendonk-de Leeuw, A.M., Haring, R.M. and Daas, J.H.G. den. (1996): Fresh semen field trial in the Netherlands. Proceedings Int. Conf Anim. Reprod. Sydney, Australia 3, 24-11.

Love, C.C., Garcia, M.C., Riera, F.R. and Kenney, R.M. (1991): Use of testicular volume to predict daily sperm output in the stallion. J. Reprod. Fert. (Suppl. 44), 99-105.

Mahon GAT, Cunningham EP. (1982): Inbreeding and the inheritance of fertility in the thoroughbred mare. Livest Prod Sci; 9, 949-953.

Malmgren, L., Kamp, B. op den, Wöckener, A., Boyle, M. and Colenbrander, B. (1994): Motility, velocity, and acrosome integrity of equine spermatozoa stored under different conditions. Reprod. Dom. Anim. 29, 469- 476.

McDowell, K.J., Powell, D.G. and Baker, C.B. (1992): Effect of book size and the age of the mare and stallion on foaling rates in thoroughbred horses. J. Equine Vet. Sci. Vol 12 (6), 364-367.

McDowell K.J., Powell D.G., Baker C.B. (1992): Effect of booksize and age of mare and stallion on foaling rates in thoroughbred horses. J Equine Vet Sci; 12, 364-367.

Parlevliet, J., Malmgren, L., Boyle, M., Wöckener, A., Bader, H. and Colenbrander, B. (1992): Influence of conservation method on the motility and morphology of stallion semen (an international project). Acta Vet. Scand. 88, 153-162.
Parlevliet, J.M., Kemp, B. and Colenbrander, B. (1994): Reproductive characteristics and semenquality in maiden Dutch Warmblood stallions. J. Reprod. Fert. 101, 183-187.

Parlevliet, J.M., Bleumink-Pluym, N.M.C., Houwers, D.J., Remmen, J.L.A.M., Sluijter, F.J.H. and Colenbrander, B. (1997): Epidemiologic aspects of Taylorella equigenitalis. Theriogenology 47, 1169-1177.

Parlevliet J.M. (1997): Clinical aspects of stallion fertility. PhD-thesis. Utrecht, the Netherlands.

Parlevliet Joyce M. and Colenbrander B. (1999): Prediction of first season stallion fertility of 3-year-old Dutch Warmbloods with prebreeding assessment of percentage morphologically normal live sperm. Equine Vet. J., 1999; Vol. 31 (3), 248-251.

Pickett and Back (1973): Procedures for preparation, collection, evaluation and insemination of stallion semen. Collorado State Univ. Exp. Sta., Gen. Ser. 935.

Pickett, B.W., Voss, J.L., Bowen, R.A., Squires, 'E.L. and McKinnon, A.O. (1987): Seminal characteristics and total scrotal width (TSW) of normal and abnormal stallions. Proc. Am. Ass. Equine Prac. 33, 487-518.

Pickett, B.W., Amann, R.P., McKinnon, A.O., Squires, E.L. and Vos, J.L. (1989): Management of the stallion for maximum reproductive efficiency, II. Animal Reproduction laboratory, Colorado State University, Fort Collins, Colorado, USA, 59-66.

Pickett, B.W. (1993): Factors affecting sperm production and sperm output. In: (editor MCKinnon, A.O. and Voss, J.L.) Equine reproduction. Lea \& Febiger, Philadelphia, London, USA, 689-704.

Rasbech, N.O. (1984): Instrumentalinseminering I hesteavlen. Dansk Veteriaer Tidsskrift 67, 1-6.

Samper, J.C., Hellander, J.C. and Crabo, B.G. (1991): Relationship between the fertility of fresh and frozen stallion semen and semen quality. J. Reprod. Fert. (Suppl 44), 107-114.

Schaaf, A. van de. (1952): Vitaal kleuring van stierensperma met een oplossing van anilineblauw en eosine. Tijdschrift voor Diergeneeskunde $77,815-818$.

Udala J. (1988): Der genetische Einflus auf die Spermaqualität von Bullen in Abhängigkeit von ihrer Abstammung. Tierzucht; 42, 234-235.

Voss JL, Pickett BW, Loomis PR. (1982): The relationship between semen characteristics and fertility in Thoroughbred stallions. J Reprod Fert; 32, 635

Joyce M. Parlevliet, DVM, PhD

Department of Equine Sciences section Reproduction

Faculty of Veterinary Medicine

Utrecht University

Yalelaan 7

De Uithof

3584 CL Utrecht

the Netherlands

tel. ${ }^{* * 31302531044}$

fax. ${ }^{* * 31302531054}$

email:j.m.parlevliet@vet.uu.nl 